\title{
THE NEXUS OF ECONOMIC GROWTH AND ENVIRONMENTAL PERFORMANCE IN MALAYSIA
}

\author{
TZE SAN ONG ${ }^{*}$, BABATUNJI SAMUEL ADEDEJI ${ }^{1}$, KAH KAH CHEAH ${ }^{1}$, CHEE LEONG \\ TAN $^{1}$, BOON HENG TEH ${ }^{2}$ AND JOSEPH MASOUD ${ }^{3}$
}

${ }^{1}$ School of Business and Economics, Universiti Putra Malaysia, 43300 Serdang, Selangor, Malaysia. ${ }^{2}$ Faculty of Management, Multimedia University, 63100 Cyberjaya, Selangor, Malaysia. ${ }^{3}$ Holmes Institute, 185 Spring St, Melbourne, Victoria, 3000 , Australia.

*Corresponding author: tzesan@upm.edu.my

Submitted final draft: 4 December 2020 Accepted: 25 December $2020 \quad$ http://doi.org/10.46754/jssm.2021.10.013

\begin{abstract}
This study aims to investigate the relationship between economic growth and the Environmental Performance Index. It also seeks to assess the trend of economic growth and environmental performance. This research uses a quantitative research method. The data for economic growth and environmental performance index in Malaysia are extracted from the World Bank and Yale Environmental Performance Index, respectively, from 2002 to 2017. The findings indicate that Gross Domestic Product growth has a significant and negative effect on the Environmental Performance Index. Population growth also showed a negative impact on environmental performance. However, there is a positive relationship between Foreign Direct Investment, agriculture added value, export goods and services, and environmental performance. The results of the study revealed that the low environmental performance index in Malaysia is caused by the growth in the manufacturing sector. This paper has added value from the perspective of enhancement of policymaking concerning public finance and environmental performance.
\end{abstract}

Keywords: GDP, population, FDI, agriculture added value, export goods and services, environmental performance.

\section{Introduction}

An economy refers to the wealth and resources a country or region is endowed with, especially concerning the production and consumption of goods and services. In the view of the Centre for the Advancement of the Steady State Economy, economic growth occurs when there is an increase in the multiplied products of the population, real gross domestic product, and per capita consumption. In other words, when production and consumption of goods and services are increased, the economy is growing.

Since the past two decades, the Malaysian economy has not only grown relatively rapidly, but it has also changed structurally, as the country moves to a manufacturing economy from agricultural production. The increase in domestic demand has driven the Malaysian economy recently thanks to the expanded private sector activities, as well as the smooth, yet constantly growing export volumes.

In recent years, a 2008 Commission on Growth Development report marked Malaysia, together with the other 13 countries at the time, as one of the fast-growing Asian economies. As evidence, it was reported that the growth rate of the Malaysian economy has been at least seven percent per year over the past 25 years.

In terms of freedom in economy, the 2015 Index of Economic Freedom showed that Malaysia had a score on 70.8, making the country the $31^{\text {st }}$ freest economy in the world that year. Since economic freedom in areas like corruption, business, and trade compensates for the lack of sufficient freedom in labour and government spending management, the overall freedom score increased to 72 in 2016. Overall, Malaysia's freedom score is better than the world's average, and in the Asia-Pacific region, it ranked as the $8^{\text {th }}$ freest economy among 42 countries in the region.

Although Malaysia has reached a defining moment in its development path, with the latest total population in Malaysia being 29.9 million, and the gross domestic product being worth US\$326.9 billion in 2014, Malaysia does 
not have an excellent useful environmental performance index. There is a fundamental conflict between economic growth and the ecological services underpinning the social economy.

Since Malaysia's ratifications of the Kyoto Protocol in 2002, the country has established numerous initiatives to reduce carbon emissions. Despite various initiatives by the government, Malaysia's ranking in the Environmental Performance Index (EPI), which is recorded once in every two years, has been on a steady decline since 2014. The Environmental Performance Index (EPI) is a comprehensive set of indicators to track environmental performances over time. Using EPI, the environmental performance of a nation's policies is numerated. This index measures performance in terms of the health of environment, which assesses how protected people are from environmental harm, and the vitality of ecosystem, which deals with resource management and ecosystem protection. Each of these two aspects provide details on nine issues, which are health impacts, air quality, water and sanitation, water resources, agriculture, forests, fisheries, biodiversity, and energy. Based on the Environmental Performance Index (EPI), Malaysia is ranked 68 in the world, slightly lower than the rank in 2018, but still considered significantly high in terms of pollutions (Wendling, Emerson, de Sherbinin, \& Esty, 2020). In previous years, Malaysia was ranked 75 out of 180 countries in 2018 (Yale University, 2018), 63 in 2016, and 51 in 2014 (Malaysia Productivity Corporation, 2016). The drops in ranking indicate that Malaysia's initiatives to reduce carbon emissions have yet to reach their goals. Despite Malaysia's ranking rising to 68 in 2020, there is not much difference compared with the previous year's rank in terms of carbon emission pollution. Malaysia might need to be proactive in reducing emissions as the carbon emission per capita by Malaysia is relatively high compared with other developing countries (Ibrahim, Shabudin, Chacko Koshy, \& Asrar, 2016).

In a nutshell, it is significant to know the EPI of our country as it can show how the country is performing other than the economic aspect, and also assist our nation in providing future targets and better improvements. Consequently, Malaysia can achieve the New Economic Model (NEM) by using and implementing the Economic Transformation Programme (ETP), which paves the country's way to become a more advanced nation while still meeting sustainability guidelines.

Besides, this study intends to address the gap created by technological advancements due to the increase in economic growth and environmental performance issues within the Malaysian economy.

\section{Problem Statement}

Palm oil production has been the main production and export of Malaysia in the past 30 years. However, the industrial sector has been growing at the cost of the nation's environment. Examples include, but not limited to, deforestation, depletion of flora and fauna, air and water pollution, and conflicts on native lands (NCLs).

According to Li (2014), 2014 was a year that was marked with distressing environmental issues for Malaysia. It was a year that saw widespread deforestation, unpredictable weather, wildlife poaching, and potentially destructive development schemes. Bukit Kiara was one of the most popular walking and biking spots in Kuala Lumpur, but, unfortunately, the land was hijacked by property developers, and fences have been erected around the park. The Malaysian Insider (19 July 2015) published that Bukit Kiara, the last green lung in Kuala Lumpur (KL), was under threat.

Malaysia is a well-known country in terms of significant economic development, but it is not doing well in terms of the environment. In 2008, Malaysia ranked $28^{\text {th }}$ in EPI. But in 2016, its ranking dropped to 63 among 180 countries, with a score of 74.23 . The indicators are divided into two aspects, environmental health and ecosystem vitality. Among the nine aspects mentioned above for each EPI scope, 
water resources, forests, and climate and energy are the most important ones to be considered as their scores is relatively low (Global Metrics for the Environment, 2016).

The study by Najam (2007) highlights the increased demand for critical yet limited natural resources in the world, which is in line with globalisation. Although economic growth is stimulated, degradation threat heightened. In other words, when an economy is growing, more pressure will be put on the environment.

Malaysia has experienced an acceleration of economic growth, which is measured by gross domestic product (GDP), human capital (population), and financial development (FD). In 2010, Malaysia launched the New Economic Model (NEM), which aims to propel the country towards high-income status by 2020 while ensuring that the growth is also sustainable and inclusive. However, Malaysia's economy is expected to contract by 3.1 percent in 2020 because of the gradual downward trends in economic activity due to the COVID-19 pandemic (World Bank Report, 2020).

Although Malaysia aims to achieve highincome status by 2020, Malaysia is also a country that significantly emphasises the environmental aspect. Malaysia also takes the initiative to improve its environmental performance by introducing a couple of environmental policies. For instance, the National Green Technology Policy was launched by the Prime Minister of Malaysia, Dato' Sri Najib Razak, on 24 July 2009.

According to Nair et al. (2014), the government had allocated RM243 million for replanting programmes for cocoa, forest, oil palm, and rubber. Besides that, another RM15 million was also allocated for launching grants to establish a Malaysian Green Foundation to promote the use of green technology in the corporate sector. The government also took the initiative to implement the National Carbon Reporting Programme (MYCarbon) in the corporate area under the Ministry of Natural Resources and Environment.
Therefore, the trade-off between economic performance and environmental performance is becoming a critical aspect of economic policy debates at all levels. The relationship between economic growth and environmental quality is in question. It can be assumed that the more the economy grows, the more the environment is polluted.

However, it is not unnecessary to showcase that economic growth inflicts damage on the environment. Therefore, research on the impact of economic growth on environmental quality is very much needed as there is limited study on the effects of economic growth on the Environmental Performance Index in Malaysia. It is hoped that this study will provide useful insights for citizens and future generations in achieving environmental sustainability in Malaysia.

\section{Research Objectives}

1. To investigate the relationship between economic growth and the Environmental Performance Index.

2. To assess the trend of economic growth and environmental performance in Malaysia.

\section{Literature Review}

\section{Environmental Kuznets Curve Theory}

According to Shafik and Sushenjit (1992) and Panayotou (1993), the relationship between economic growth and environmental quality is not linear. In certain economic stages, people will prioritise and demand environmental protection. The Ushaped relationship illustrated above is named the "environmental Kuznets curve", which is inspired by economist Simon Kuznets, who defined the same pattern for income inequality (Andrée et al., 2019).

Based on this curve, the economic development stage does not significantly damage the environment and biodegradable wastes are limited. Both resource depletion and waste generation accelerate as agriculture and resource extraction intensifies, and industrialisation takes 


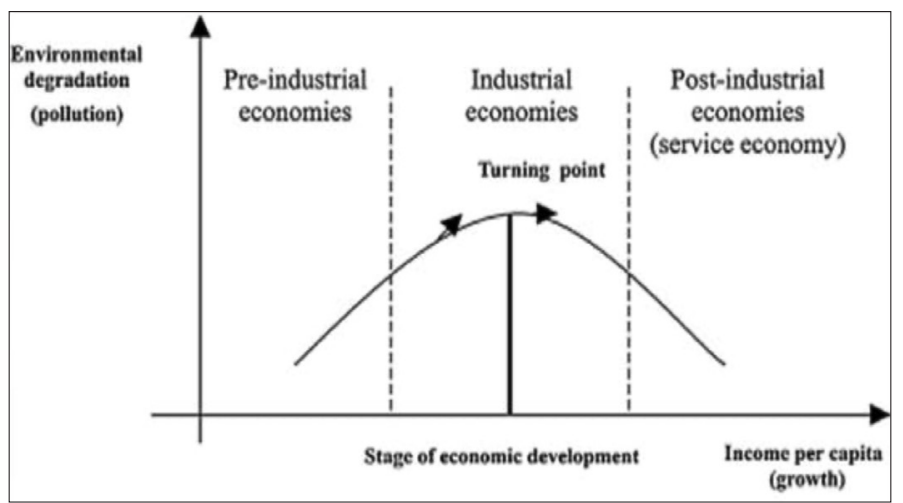

Figure 1: The Environmental Kuznets curve: A development-environment relationship

off. At higher levels of development, there will be a structural change towards informationbased industries and services and more efficient technologies. Thus, this will lead to an increase in demand for environmental quality, which results in a levelling off and a steady decline in environmental degradation.

The Kuznets curve theory offers critical policy implications for nations. At the preindustrial and industrial stages, nations must be alerted to reduce the speed of economic growth to save the environment, while countries at the post-industrial stage benefit from improved environmental performance.

At the other extreme, Beckerman (1992) and Pettinger (2019) also state that the fastest road to environmental improvement is along the path of economic growth with higher incomes, which come from increased demand for goods and services. The implications are less material intensive, as well as demand for improved environmental quality that leads to the adoption of environmental protection measures. According to Beckerman (1992), income is positively correlated to environmental protection, in that a country wishes to protect its environment in the long term, which is the most effective way is to become wealthy.

The current study examines the role of domestic material consumption, income and renewable energy utilisation according to the panel of the EU-28 environmental sustainability targets. In specific, we find that domestic material consumption worsens the bloc's environmental quality in both the immediate and long term. Although an increase in per capita income level aids environmental sustainability in the long term, the short-run effect shows that per capita income growth triggers greenhouse gas emissions.

\section{Environmental Performance Index and Economic Growth}

Diakaki, Grigorousdis and Stabouli (2006) defined environmental performance as principles of risk assessment of environmental degradation and key techniques in the protection and management of the environment. The Environmental Performance Index (EPI) is a well-constructed indicator of environmental performance, which covers all aspects of a country's environmental activities and provides the identification of the most significant indicators to be considered for the evaluation of environmental performance. The EPI provides a basis for evaluating the relationship between economic competitiveness and environmental protection. Usually, top-ranked countries are among the most productive and competitive in the world. A country's economic development is a crucial determinant of environmental outcomes. However, policy choices also affect performance. Developed countries always suffer from pollution and degraded ecosystems, while developing countries face an additional burden of investing in water and sanitation systems (Loucks \& Van Beek, 2017). 
Economic growth refers to the raise of economic activity to generate and consume goods and services over a timeframe. Economic growth is desirable to provide better quality of life while maintaining environmental sustainability (WCED, 1987).

McConnell (1997) has a more comprehensive research on income and demand for environmental quality. In the study, the relationship between income elasticity and environmental excellence demand in EKC was investigated. The results presented by McConnell shows that environmental pollution would be reduced when income elasticity increases.

However, there is no unique role assigned to income elasticity that is equal to or greater than one. Ota (2017) posits that growth influences income inequality, as environmental degradation is not the same among high-income economies, but among lower-income countries, the effects of growth on inequality are little, though its influences on the environment is substantial. While environmental and income policies are sparingly available for low-income countries, high-income nations have developed different policies to address growing income inequality and environmental degradation.

The income-environment relationship, as specified and tested in much of the literature, is a reduced form function that aims to capture the "net effect" of income on the environment. Revenue provides an omnibus variable, representing a variety of underlying influences, whose separate effects become obscured. For this reason, some researchers have termed the reduced form specification as a "black box" that hides more than it reveals without explicit consideration of the underlying determinants of environmental quality, and the scope of policy intervention is unduly circumscribed (Panayotou, 1997).

Based on the research by Islam et al. (1999), the three separate fundamental forces that affect the environment are the scale of economic activity, the composition or structure of economic activity, and the effect of income on the demand and supply of pollution abatement efforts. Economic growth changes the structure of the economy, which will pollute environment to varying extents. On one hand, the lower the income of a nation, the higher the tendency towards the industrial sector, which increases environmental pollution. On the other hand, societies with higher income levels will choose a service-based economy, which reduces the threat to the environment.

For instance, the percentage of industryfirst rises and falls, environmental pollution will rise and then decrease with income growth, controlling for all other influences transmitted through income.

Panyotou (1993 \& 1997) discussed that the primary needs, like food and shelter, are dominant economic targets in low-income countries, which deviates attention from environmental considerations. Contrary to this, pollution reduction is significantly considered and invested by both private and public sectors in high-income economies, which leads to more disciplined and regulated environmental rules and guidelines.

In short, Panayotou (1997) concluded that "higher incomes tend to be associated with improved monitoring possibilities, and hence, accelerate the speed of social adjustments, which, in turn, lowers the gap between the speed of environmental change and social change."

It is proven that economic growth and environmental quality are mutually related to each other over time (Ghisellini et al., 2015). However, this connection is not straightforward, and there is dispute on whether the connection is either positive or negative, as the existing literature are divided on the topic, and hence the issue remains controversial.

The current study is quite different from the research conducted by Alola, Akadiri and Usman (2020), which examined the significance of domestic material consumption, income and renewable energy usage according to the EU28 environmental sustainability targets. They opined that domestic material consumption minimises the bloc's environmental quality 
from the immediate and long-term perspectives. Also, it was evident from the outcome of their study that environmental sustainability in the long term is enhanced by the increase in per capita income level, and the short-run impact demonstrates that per capita income growth causes environmental pollution.

To sum it up, it is expected that economic growth (income) would increase the demand for environmental protection in society as a whole. Countries with higher income per capita will generally have better industrial environmental performance. Environmental quality is a luxury good, and it is demanded more with increased income. Thus, developing the economy is a crucial policy goal from the perspective of environmental progress.

\section{Hypothesis Development}

\section{Gross Domestic Product Affects the Environmental Performance Index}

Gross domestic product is an indicator of a country's economic health and gauges the country's standard of living. It represents the monetary value of all goods and services produced within a nation over a specified period.

Grossman and Kruger (1991) carried the first study on economic development and the environment, and they evaluated the effects of free trade in North America to investigate the relationship between pollution and economic development. They made use of GDP per capita, time trend, and pollution indices, such as the spread of dioxide sulphur and suspended Particulate Matter (SPM) in the air. The results indicated a reversed U-shaped link between GDP per capita and the amount of the spread of sulphur dioxide.

Frankel and Rose (2005) showed that the higher the trade, the higher the production, and, as a result, the higher the environmental pollution. Their study included other variables, such as original variable, gross product per capita, the level of democracy, and population density, together with GDP per capita. in their analysis.
Based on the above discussion, GDP is likely to affect the EPI of a country.

\section{H1: The GDP is significantly related to the EPI.}

\section{Foreign Direct Investments (FDI) Affect the Environmental Performance Index}

Foreign direct investments are the direct investment equity flow in the reporting economy. They are the sum of equity capital, reinvestment of earnings, and other capital. The benefits of FDI in providing direct capital financing and generating positive externalities are explained by Lee (2013). It is argued that FDI underpin economic growth through the transfer of technology, which improves a country's productivity, introduces updated processes and increases managerial skills.

However, past research shows mixing effects for the effects of FDI and economic growth on environmental sustainability. The Porter hypothesis, developed by Porter (1991), can help direct attention to the effect that FDI have.

According to the Porter hypothesis, manufacturers and producers will be forced to innovate when environmental policies are strictly imposed. Even though such compliance comes at a cost, Mihci et al. (2005) stated that such a cost ultimately leads to the advent of new technologies that protect the environment and, hence, compensate for the cost of compliance. Palmer et al. (1995), however, opposed the Porter hypothesis because they believed that such innovations will be created only when the benefits outweighed the cost, which is not considered in the Porter hypothesis.

Generally speaking, the higher the FDI, the higher the environmental degradation. The study by Beak and Koo (2009) supports this, as they showed that FDI increased energy consumption in China. But, in India, FDI had a significant effect on environmental pollution for a short term, but it did not affect the Indian environment in the long run. Also, $\mathrm{CO} 2$ emissions increase 
when the economy grows, which obviously damages the environment and air quality.

Muhammad et al. (2015) studied the influence of FDI in high-, middle-, and lowincome countries. They concluded that FDI reduce $\mathrm{CO} 2$ emissions at every stage of economic growth in high-income countries, but not in low-income countries. Through causality analysis, $\mathrm{CO} 2$ emission and energy consumption become interrelated globally, as well as in highand middle-income panels. The latter indicates that FDI policies in low-income countries will lead to a degradation of the environment. In low-income countries, the aftermath of the FDI targeting industry and production sectors is the increased environmental biodegradation and pollution.

Based on the above discussion, it can be concluded that FDI is likely to affect the EPI of a country.

H2: The FDI is significantly related to the EPI.

\section{Value-Added Agriculture (\% of GDP) Affects the Environmental Performance Index}

Value-added agriculture is the process of changing or transforming a product from its original state to a more valuable state (Boland, 2009). Producers can gain more revenue as a result of changing the physical state of their products.

Zibaei and Shaykh Zayn Aldin (2009) used species diversity and income per capita in biological diversity and economic development to investigate the link between biological diversity and economic development in 121 countries, especially the developing counties for the year 2002. OCED countries also state that agriculture makes intensive use of inputs, resulting in high crop and livestock yields in comparison to other OCED countries. They also studied the effect of value-added agriculture, the free-trade index, trade rate, climate, and energy on environmental diversity. The results show that they have a negative and significant impact on ecological diversity.
Based on the above discussion, the view is that value-added agriculture is likely to affect the EPI of a country.

\section{H3: Value-added agriculture is significantly related to the EPI.}

\section{Population Affects the Environmental Performance Index (Energy Consumption)}

Past studies have shown that population and economic growths are major driving forces behind increased energy use, and this leads to the emission of carbon dioxide (CO2). Newman and Kenworthy (1989), in a pioneering study, also indicate that there is a negative correlation between population density and gasoline consumption using cross-sectional data from 32 large cities around the world from 1980. Batliwala and Reddy (1993) also noted that energy demand depends on per capita energy use.

Furthermore, York et al. (2003) stated that energy use concerning the population is close to unity. As the living standard rises and society continues to grow, energy use, and $\mathrm{CO} 2$ emissions in city areas do the same (Fong et al., 2007). Liddle (2004) also discovered that urbanisation and population density had a negative effect on the per capita contribution of road transport energy use. Thus, the implication is that populous, highly urban cities have less demand for personal transport.

With regard to urbanisation, sprawl measurement plays a significant role in environmental pollution. As evidence, an analysis conducted by Ewing and Rong (2008) in the US for the year 2001 showed that the higher the sprawling rate, with every family living in big self-standing houses, the more energy was consumed, compared with countries with compact residential premises.

Garau et al. (2013) studied the relationship between population and energy usage in Italy. The results showed that the older and aging population consumes less energy, but the choice of goods and services of the aging population consumes more energy. In Malaysia, a study 
by Shaari et al. (2013) revealed that population had a significant and positive effect on energy consumption over the span of two decades, from 1991 to 2011.

However, Malaysia has an inferior transportation system, and thus, this leads to an increase in energy consumption. The higher the energy consumption, the higher the emission of carbon dioxide. Consequently, this will cause air pollution. As a result, the opinion is that there is a negative correlation between population density and the Environmental Performance Index.

H4: Population density is negatively related to the EPI.

\section{Exports of Goods and Services Affect the Environmental Performance Index}

Exports of products and services represent the value of all products and other market services provided outside the domestic markets. They consist of the cost of merchandise transport, freight, insurance, royalties, and licence fees. It played a crucial role in accelerating economic growth (Arvin et al., 2015)

Although the market for environmental goods and services has been traditionally confined to developed countries and developing countries, such as Brazil, China, India, and Mexico, they appeared to become the significant exporter or importer of exports of goods and services. However, they are increasingly vulnerable to global environmental problems. They are also subject to environmental compliance while exporting to developed and developing countries.

Also, several experts have noted that expanded trade usually increases a country's wealth and will often have both positive and negative impacts on the environment (Grossmman \& Kruger, 1991; Copeland \& Taylor 2004). The typical understanding is that it is a result of scale and composition effects, as industrial production increases, there will be a higher level of pollution and stress on the ecosystem. According to Grossman and Krueger
(1995), environmental issues can be solved through the use of eco-friendly technology, as best practices can enable more efficient and environmentally sound production methods.

Based on the above discussion, it can be concluded that exports of goods and services are likely to affect the EPI of a country.

\section{H5: The exports of goods and services are significantly related to the EPI.}

\section{Methodology}

This study focuses on the economic growth and Environmental Performance Index (EPI) between 2002 and 2017. The data used in this study were taken from the World Development Indicator 2017, while the data on environmental performance were obtained from the Yale Environmental Performance Index 2017. There are five proxies, which are gross domestic product, foreign direct investment, value-added agriculture, population, and exports of goods and services, which are the independent variables. For the dependent variables, its proxies are health impacts, air quality, water and sanitation, water resources, agriculture, forests, fisheries, biodiversity, and climate and energy. Table 1 below shows the mapping of research variables, the operationalisation and the related studies.

\section{Regression Model}

In this research, the regression model was developed to explore the association between income (GDP), population (POP), financial development (FD) and the Environmental Performance Index (EPI), which is:

Model 1: $\mathrm{EPI}=\alpha+\beta$ GDP $+\beta$ POP $+\beta$ FD $+\varepsilon$

\section{Result and Discussions}

\section{Descriptive Analysis}

Table 2 shows the descriptive statistics for 14 observations based on the period between 2002 to 2015 . The mean value for the EPI is $1.81 \%$. The population growth is about $7.44 \%$. The mean for exports of goods and services is $0.46 \%$, and the GDP growth is about $0.7 \%$. Foreign 
Table 1: Operationalisation and related studies of the research variables

\begin{tabular}{|c|c|c|}
\hline Variables & Operationalization & Related Studies \\
\hline $\begin{array}{l}\text { Dependent variables: } \\
\text { Environmental Performance } \\
\text { Index (EPI) }\end{array}$ & $\begin{array}{l}\text { Environmental Performance } \\
\text { Index } \\
\text { Score: } 1-100 \%\end{array}$ & (Kraemer \& Peichert, 2007) \\
\hline $\begin{array}{l}\text { Independent variables: } \\
\text { Income }\end{array}$ & $\begin{array}{l}\text { Gross Domestic Product } \\
(G D P) \text { per capita }\end{array}$ & (McConnell, 1997; Ota, 2017) \\
\hline Foreign direct investment & $\begin{array}{l}\text { Foreign direct investment, net } \\
\text { inflows (\% of } G D P)\end{array}$ & $\begin{array}{l}\text { (Lee, 2013; Mihci et al., 2005; Porter, } \\
\text { 1991; Van der Linde, 1995; Esty \& } \\
\text { Porter, 1998; Palmer et al., 1995; } \\
\text { Beak* Koo, 2009; Muhammad et al., } \\
\text { 2015) }\end{array}$ \\
\hline Value-added agriculture & $\begin{array}{l}\text { Value-added agriculture (\% of } \\
G D P)\end{array}$ & $\begin{array}{l}\text { (Boland, 2009); Zibaee \& Sheikh Zein- } \\
\text { Al-din, 2009) }\end{array}$ \\
\hline Exports of goods and services & Population total & $\begin{array}{l}\text { (Newman \& Kenworthy, 1989; } \\
\text { Batliwala \& Reddy, 1993; Fong et al., } \\
\text { 2007; Ewing \& Rong, 2008; Garau et } \\
\text { al., 2013) }\end{array}$ \\
\hline & $\begin{array}{l}\text { Exports of goods and services } \\
\text { (annual \% growth) }\end{array}$ & $\begin{array}{l}\text { (Grossmman \& Kruger, 1991; } \\
\text { Copeland \& Taylor, 2004; Kahuthu, } \\
\text { 2006) }\end{array}$ \\
\hline
\end{tabular}

Table 2: Descriptive results of the research variables

\begin{tabular}{lcccccc}
\hline & LOG10EPI & $\begin{array}{c}\text { LOG10GDP } \\
\text { GROWTH }\end{array}$ & LOG10FDI & LOG10AGRI & $\begin{array}{c}\text { LOG10POP } \\
\text { GROWTH }\end{array}$ & LOG10GS \\
\hline Mean & 1.805714 & 0.695000 & 9.735714 & 0.355000 & 7.437857 & 0.462143 \\
\hline Median & 1.800000 & 0.745000 & 9.920000 & 0.435000 & 7.435000 & 0.710000 \\
\hline Maximum & 1.920000 & 0.870000 & 10.18000 & 0.840000 & 7.490000 & 1.210000 \\
\hline Minimum & 1.690000 & -0.180000 & 8.060000 & -1.280000 & 7.390000 & -1.040000 \\
\hline Std. Dev. & 0.084645 & 0.258688 & 0.537297 & 0.534023 & 0.031666 & 0.650954 \\
\hline Skewness & 0.251754 & 0.498870 & -1.322631 & -0.150090 & 0.067724 & -0.476315 \\
\hline Kurtosis & 1.791134 & 2.88159 & 3.042375 & 3.441650 & 1.827463 & 3.267519 \\
\hline Jarque-Bera & 1.000345 & 0.58736 & 6.83656 & 2.29488 & 0.812694 & 3.270420 \\
\hline Probability & 0.606426 & 0.000000 & 0.000001 & 0.000014 & 0.666079 & 0.194911 \\
\hline Sum & 25.28000 & 9.730000 & 55.09577 & 4.970000 & 6.451327 & 6.470000 \\
\hline Sum Sq. Dev. & 0.093143 & 0.869950 & 0.191415 & 3.707350 & 0.098217 & 5.508636 \\
\hline
\end{tabular}

direct investments indicate a high concentration The standard deviation for population growth in the sample at $9.7 \%$. However, value-added is $0.03 \%$. This indicates that the variation in agriculture was lowest in the sample, at $0.36 \%$. population growth and other variables is small. 
Based on the maximum and minimum value, the results show that no expected outlier in the analysis.

\section{Correlation between Variables}

Table 3 represents the correlation between variables. It shows that the Environmental Performance Index (EPI) score has a positive association with population growth (LOG10 POPGROWTH). However, EPI has a negative relationship with gross domestic product growth (GDPGROWTH), foreign direct investments (FDI), value-added agriculture (AGRI), and exports of goods and services (GS). They have a low negative correlation as the range of the relationship is between -0.1 to -0.4 .

Besides that, gross domestic product growth and foreign direct investments (FDI) have a higher positive relationship, as highlighted above. This indicates that a tendency of multicollinearity problems arises if there is a high correlation among independent variables in a model (Pearson's Correlation Coefficient). GDP growth and foreign direct investments (FDI) are positively correlated because GDP growth will affect FDI. GDP represents the monetary value of all the goods and services produced in a country over a specified period of time. Cost efficiency of production and the realisation of economies of scale and scope in production are linked with market size (Blonigen et al., 2007). A growing market can be attractive to FDI because a more significant market will enable a more efficient scale of production through the realisation of economies of scale. (Agosin and Machado, 2007). Therefore, GDP growth and FDI become positively related as naturally growing economies provide growth prospects for more profitable investments.

Multicollinearity was tested via a variable inflation factor (VIF). Cooper and Schindler (2011) stated that the VIF value of 10.0 or more indicates collinearity or multicollinearity. Thus, Table 4 shows that there is no multicollinearity issue as the VIF value is less than 10.0.

\section{Regression Model/Hypothesis Results}

Based on the regression result in Table 5, our model is as below:

$$
\begin{aligned}
& \text { LG10 }(\text { EPI })=0.42-0.77 \text { LG10 }(\text { GDPGROWTH }) \\
& +0.38 \text { LG10 (FDI) + 0.09 LG10 (AGRI) }-0.09 \\
& \text { LG10 (POPGROWTH) + 0.06 LG10 (GS) }
\end{aligned}
$$

The model has an adjusted R-squared of 97.28\% with the Prob (F-statistic) of less than $5 \%$. Hence, it can be concluded that there is a significant relationship between EPI and economic growth in Malaysia.

According to a previous study, it was found that the Environmental Performance Index (EPI) is significantly related to economic growth in Malaysia. Exports of goods and services and value-added agriculture are positively related to EPI. On the other hand, gross domestic product

Table 3: Correlation results of the research variables

\begin{tabular}{lcccccc}
\hline & LOG10EPI & $\begin{array}{c}\text { LOG10 } \\
\text { GDP } \\
\text { GROWTH }\end{array}$ & $\begin{array}{c}\text { LOG10 } \\
\text { FDI }\end{array}$ & $\begin{array}{c}\text { LOG10 } \\
\text { AGRI }\end{array}$ & $\begin{array}{c}\text { LOG10 POP } \\
\text { GROWTH }\end{array}$ & LOG10GS \\
\hline LOG10EPI & 1.0000 & & & & & \\
\hline $\begin{array}{l}\text { LOG10 GDP } \\
\text { GROWTH }\end{array}$ & -0.4065 & 1.0000 & & & & \\
\hline LOG10FDI & -0.1234 & 0.8852 & 1.0000 & & 1.0000 & \\
\hline LOG10AGRI & -0.3945 & 0.8612 & 0.7512 & 1.0000 & & \\
\hline $\begin{array}{l}\text { LOG10POP } \\
\text { GROWTH }\end{array}$ & 0.2230 & 0.0070 & 0.3661 & -0.1444 & & \\
\hline LOG10GS & -0.4266 & 0.7612 & 0.4969 & 0.7598 & -0.3095 & 1.0000 \\
\hline
\end{tabular}


Table 4: Collinearity results of the research variables

\begin{tabular}{lcc}
\hline \multicolumn{1}{c}{ Model } & \multicolumn{2}{c}{ Collinearity Statistics } \\
\cline { 2 - 3 } & Tolerance & VIF \\
\hline LG10 (GDPGROWTH) & 0.162 & 6.158 \\
G10 (FDI) & 0.186 & 5.377 \\
LG10 (AGRI) & 0.243 & 4.121 \\
LG10 (POP) & 0.219 & 4.842 \\
LG10 (GS) & 0.244 & 4.105 \\
\hline
\end{tabular}

Dependent Variable: LG10 (EPI)

growth and urban population have a negative relationship with EPI.

Based on the findings, gross domestic product growth is negatively related to EPI. An average of $0.01 \%$ of GDP will have much influence on EPI. In other words, this means that the GDP growth rate will have negative consequences towards Malaysia's EPI score. An increase in GDP will cause the EPI score to decrease. This result may be due to the diminishment of environmental resources from the production of goods, and negligent ecological protection policies in the country. Malaysia should set a higher protection policy to achieve a better EPI score. For example, when a proposal for a new plantation is put forward, the government should assign environmental scientists or specialists to evaluate the impact of the estate on the ecological health of the country.

Besides that, there is also a positive association between foreign direct investment (FDI) growth and EPI. FDI is cleaner than domestic investment as FDI in Malaysia involves new technologies that are cleaner than local producers, leading to improvements in environmental performance. This is because FDI increases the demand for environmental quality. According to the environmental Kuznets curve, when income rises, the need for the environmental quality will increase, and this will thus lead to a better EPI score. The related regulators should design a comprehensive economic and policy model of sustainability. This analysis is significant to motivate proposals for a range of regulatory and market instruments that can help FDI promote the transition to sustainability.

Also, value-added agriculture is positively related to EPI. Value-added agriculture tends to improve Malaysia's EPI score. An average of $68 \%$ increase in value-added agriculture has the best influence on the EPI. The implication is that when the production of agriculture is higher, the EPI score is higher. This may be due to the technology used for agriculture to cut down on environmental harm. For example, MARDI develops techniques and technologies that allow farmers to manage their farms more efficiently. Furthermore, nowadays, modern and efficient processing technologies have been introduced, alongside training programmes that highlight agronomic practices, as well as new agriculture techniques and technologies, which are provided to farmers and fishermen for better productivity.

Apart from that, population growth is negatively related to EPI. An average of $23 \%$ of urban population growth will decrease the EPI score. This is because urbanisation leads to losses in highly productive farmland, affects energy demand, is linked to climate change, and reduces biodiversity. In Malaysia, the increase in the urban population growth rate is mainly due to the development of the manufacturing sector, which leads to the introduction to cities. The rapid growth of these industries, such as the manufacturing sector, is the main factor of the environmental deterioration, resulting in a lower EPI score. Consequently, this will cause loss of forests due to the high demand for property, which eventually leads to the distortion of natural wood. 
Lastly, there is also a significant relationship between exports of goods and services and the EPI. An average of $9 \%$ increase in exports of products and services will have an impact on EPI. ThWhen the exports of products and services are high, the EPI score will be high. This happens as the government gains higher taxation due to the higher exports of goods and services. As a result, this will increase the country's revenue, allowing more funds to be allocated for environmental protection projects.

\section{Discussion}

One of the objectives of this research is to identify the relationship between economic growth and environmental quality in Malaysia. A few proxies of economic growth were chosen to assess the relationship between EPI and economic growth in Malaysia and, subsequently, construct a model. The higher economic growth, the better the country's EPI score. In other words, wealthier countries will have a higher EPI score. Malaysia is one of the top middle-income countries and is ranked 63 out of the 180 countries included in the EPI report. Hence, the findings prove that the higher economic growth, the better the EPI score. Different results were obtained when assessing the relationship between the EPI and proxies of economic growth independently. Nevertheless, most of the proxies of economic growth are significantly related to the EPI.
Moreover, the second objective is to analyse the environmental performance based on environmental health and ecosystem vitality. It is crucial to study the components of the EPI. As mentioned in the previous chapter, the EPI consists of 9 issue categories with 20 indicators that reflect how well a country scored in terms of environmental goals. The EPI index measures two broad categories, which are environmental health and ecosystem vitality, with a range from 0 to 100 . The higher the EPI score, the better the country performed in terms of environmental quality. Environmental health emphasises more on human health, while ecosystem vitality focuses more on ecosystems and natural resources. Environmental health consists of health impacts, air quality, and water and sanitation. These indicators measure of the level of protection for human health. For ecosystem vitality, they measure how well the country performed in terms of ecosystem resources. In a nutshell, it aims to reduce the stresses on human health and the loss of ecosystems and natural resources.

\section{Conclusion}

This paper investigated the relationship between the Environmental Performance Index (EPI) and economic growth in Malaysia. Exports of goods and services and value-added agriculture are positively related to the EPI. However, gross

Table 5: Regression result for the Environmental Performance Index

\begin{tabular}{|c|c|c|c|}
\hline \multicolumn{4}{|c|}{$\begin{array}{l}\text { Dependent Variable: } \log 10 \text { EPI } \\
\text { Method: Least Square }\end{array}$} \\
\hline Variable & Coefficient & P-Value & \\
\hline $\mathrm{C}$ & 0.4221 & 0.3510 & \\
\hline LG10 (GDPGROWTH) & -0.7662 & 0.0402 & \\
\hline LG10 (FDI) & 0.3762 & 0.0337 & \\
\hline LG10 (AGRI) & 0.0927 & 0.3069 & \\
\hline LG10 (POPGROWTH) & -0.0900 & 0.1831 & \\
\hline LG10 (GS) & 0.0562 & 0.3876 & \\
\hline R-squared & 0.9728 & Prob (F-statistic) & 0.000004 \\
\hline Adjusted R-squared & 0.9758 & Akaike info criterion & -2.168128 \\
\hline
\end{tabular}


domestic product growth and urban population showed a negative relationship with the EPI.

The implications of the positive relationships are that export of goods and services, on one hand, will help open the economy and encourage the production of quality goods that can compete favourably in the international domain or markets. Besides, regulators would now have the responsibility of developing laws to ensure the sustainability of the EPI ranking and motivation for harnessing FDI to expand the production frontiers. On the other hand, valueadded agriculture requires the introduction of better and advanced technological devices for the sustainability of the agricultural output that is required to further enhance capacity building of the manufacturing sector, and to create more employment opportunities in the country.

The negative relationship between EPI and GDP implies that an increase in the latter would lead higher consumption, which will stretch the capacity of the economy and thus increase the need for more monitoring to ensure that the EPI is within tolerable limits. The above assertion will involve the incurring of additional costs to ensure sustainability within the economy, especially the control of pollution due to gaseous emissions from the manufacturing sector, as well as urban traffic congestions. Also, urbanisation due to population growth is likely to over-burden the facilities within the nation (roads, electricity supply, water sewage systems, and health institutions) and the creation of extra budgetary provisions to cushion the effects of the stress on the populace, especially during the Covid-19 pandemic.

This study is limited in that emphasis was not on all the economically inclined factors, such as inflation, unemployment and interest rate, which can affect the measurement of the impact on the EPI. Therefore, future studies would be required to, in addition to factors considered in the current research, produce a robust outcome for policymakers and regulators to improve the country's EPI ranking and attract more relevant FDI into the country by virtue of the coverage of these other indices.

\section{Acknowledgements}

The authors extend their gratitude to reviewers for their critical comments on the manuscript and the university for the research opportunity. This work was supported by the Grant number 6303806-10601 (GSPE/UPM) and FRGS/1/2020/SS01/MMU/02/4.

\section{References}

Abdul Raufu Ambali, A. N. (2013). Environmental policy in Malaysia: Biomedical waste, strategies, and issues. Journal of Administrative Science, 10(1).

Center for the Advancement of the Steady State Economy. (n.d.). http://steadystate.org/.

Lee, S. (2015). Economic growth and the environment in China: Empirical. China Economic Review, 73-85.

Suhaida, M. S., KL. (2013). Green buildings in Malaysia towards the greener environment. 4th International Conference on Energy and Environment. IOP Publishing.

Saidi, K., \& Hammami, S. (2015). The impact of $\mathrm{CO} 2$ emissions and economic growth on energy. Energy Reports, 62-70.

Saidi, K. (2015). The impact of energy consumption and carbon dioxide emissions on economic growth: Fresh evidence from dynamic simultaneous -equations. Sustainable Cities and Society, 178-186.

Azam, M., Khan, A., Bakhtyar, B., \& Emirullah, C. (2015). The causal relationship between energy consumption and economic growth in the ASEAN-5 countries. Renewable and Sustainable Energy Reviews, 47(C), 732745.

Baek, C. (2014). Effects of regulation and economic environment on the electricity industry's competitiveness: A study based on OECD countries. Energy Policy, 120128.

Cowan, W. N. (2014). The nexus of electricity consumption, economic growth, and $\mathrm{CO} 2$ 
emissions in the BRICS countries. Energy Policy, 359-368.

Zhu, S., He, C., \& Liu, Y. (2014). Going green or going away: Environmental regulation, economic. Geoforum, 53-65.

Tan, F. Lean, H. H., \& Khan, H. (2014). Growth and environment quality in Singapore: Is there any trade-off? Ecological Indicators, 47, 149-155.

Afroz, R., Hassan, M. N., \& Ibrahim, N. A. (2003). Review of air population and health impacts in Malaysia. Environmental Research, 71-77.

Boucekkine, R., Krawczyk, J. B., \& Vallee, T. (2011). Environmental quality versus economic performance: A dynamic game approach. Optimal Control, Applications and Methods, 32, 29-46.

Panayotou, T. (2003). Economic growth and the environment. Economic Survey of Europe.

Suhaida, M. S., Tan, K. L., \& Leong, Y. P. (2013). Green buildings in Malaysia towards greener environment: Challenges for policymakers. 4th International Conference on Energy and Environment. IOP Publishing.

Yaacob, M. R. (April-June, 2008). Environmental management in Malaysia Palm Oil Industry: A qualitative analysis of environment nongovernmental organisations' pressure. Journal of Environmental Research and Development, 2(4).

Agosin, M. R., \& Machado, R. (2007). Openness and the international allocation of foreign direct investment. The Journal of Development Studies, 43(7), 1234-1247.

Alola, A. A., Akadiri, S. S., \& Usman, O. (2020). Domestic material consumption and greenhouse gas emissions in the EU-28 countries: Implications for environmental sustainability targets. Sustainable Development. Wiley Online.

Andrée, Bo P. J., Chamorro, A., Spencer, P., Koomen E., \& Dogo, H. (2019). Revisiting the relation between economic growth and the environment; a global assessment of deforestation, pollution, and carbon emission, Renewable and Sustainable Energy Reviews, 114, 109221, 1-16.

Arvin, M. B., Pradhan, R. P., \& Norman, N. R. (2015). Transportation intensity, urbanization, economic growth, and $\mathrm{CO} 2$ emissions in the G-20 countries. Utilities Policy, 35(C), 50-66. Elsevier. DOI: 10.1016/j.jup.2015.07.003

Batliwala, S., \& Reddy, A. K. N. (1993). Energy consumption and population. Population summit of The World's Scientific Academies. October 24-27, New Delhi (India). Retrieved on September 23, 2020 from http://www.amulyareddy.org.in/Publi cation/1993_10_SBAKNNDF.POP .pdf

Beak, J., \& Koo, W. W. (2009). A dynamic approach to FDI-environment nexus: The case of China and India. Journal of International Economic Studies, 13, 15982769.

Beckerman, W. (1992). Economic growth and the environment: Whose growth? Whose environment? World Development, 20, 48196.

Blonigen, B. A., Davies, R. B., Waddell, G. R., \& Naughton, H. T. (2007). FDI in space: Spatial autoregressive relationships in foreign direct investment. European Economic Review, 51(5), 1303-1325.

Boland. M. (2009). What is Value-added Agriculture? getting prepared/value added agriculture/articles/index.cfm. http://www. agmrc.org/business_development/.

Copeland, B. R., \& Taylor, M. S. (2004). Trade, growth, and the environment. Journal of Economic Literature, 42(1), 7-71.

Diakaki, C., Grigoroudis. E., \& Stabouli, M. (2006). A risk assessment approach in selecting environmental performance indicators. Management of Environmental Quality: An International Journal, 17(2), 126-139. 
Esty, D. C., \& Porter, M. E. (1998). Industrial ecology and competitiveness: Strategic implications for the firm. Journal of Industrial Ecology, 2(1), $35-43$.

Ewing, R., Bartholomew, K., Winkelman, S., Walters, J., \& Anderson, G. (2008a). Urban development and climate change. Journal of Urbanism, 1, 201-216.

Fong, W. K., Matsumoto, H., Lun, Y. F., \& Kimura, R. (2007). Influences of indirect lifestyle aspects and climate on household energy consumption. J. Asian Archit. Build. Eng. 6, 395-402.

Frankel, J. A., \& Rose, A. K. (2005). Is trade good or bad for the environment? Sorting out the causality. Review of Economics and Statistics, 87(1), 85-91.

Garau, G., Lecca, P., \& Mandras, G. (2013). The impact of population ageing on energy use: Evidence from Italy. Econ. Model, 35, 970-980.

Ghisellini, P., Cialani, C., \& Ulgiati, S. (2015). A review on circular economy: The expected transition to a balanced interplay of environmental and economic systems. Journal of Cleaner Production, 114(7), 1132. doi: 10.1016/j.jclepro.2015.09.007

Global Metrics for the Environment. (2016). Malaysia's Performance in Environmental Performance Index. Retrieved on 27 September 2020 from http://www.mpc. gov.my/wp-content/uploads/2016/04/EPI2016-Topline.pdf

Grossman, G. M., \& Krueger, A.B. (1991). Environment impacts of a North American Free Trade Agreement, Working Paper No.3914, National Bureau of Economic Research, Cambridge, MA, pp.1-39.

Grossman, G. M., \& Krueger, A. B. (1995). Economic growth and the environment. The Quarterly Journal of Economics, 110(2), 353-377.

Islam, N., Vincent, J., \& Panayotou, T. (1999). Unveiling the income environment relationship: An exploration into the determinants of environmental quality (p. 701). Harvard Institute for International Development Discussion Paper No: Harvard University.

Kennedy, H. P., Farrell, T., Paden, R., Hill, S., Jolivet, R. R., Cooper, B. A., \& Schindler Rising, S. (2011). A randomized clinical trial of group prenatal care in two military settings. Military medicine, 176(10), 11691177.

Kraemer, R. A., \& Peichert, H. (2007). Analysis of the Yale Environmental Performance Index (EPI). Retrieved on June 29, 2017.

Lee, J. W. (2013). The contribution of foreign direct investment to clean energy use, carbon emissions and economic growth. Energy Policy, 55, 483-489.

Li, T. C. (2014). 'The Star' editor wins green award. The Star, Monday 3 November.

Liddle, B. (2004). Demographic dynamics and per capita environmental impact: Using panel regressions and household decompositions to examine population and transport. Population and Environment, 26(1), 23-39.

Loucks D. P., \& van Beek, E. (2017). Water resources planning and management: An overview. In Water resource systems planning and management. Springer, Cham. https://doi.org/10.1007/978-3-31944234-1_1.

McConnell, K. E. (1997). Income and the demand for environmental quality. Environment and development Economics, 2(4), 383-399.

Mihci, H., Cagatay, S., \& Koska, O. (2005). The impact of environmental stringency on the foreign direct investments of the OECD countries. Journal of Environmental Assessment Policy and Management, 7(4), 679-704.

Mohammad, S., Gow, J., \& Ozturk, I. (2015). Is the long-run relationship between economic growth, electricity consumption, carbon dioxide emissions, and financial 
development in Gulf Cooperation Council Countries robust? Renewable and Sustainable Energy Reviews, 51, 317-326.

Nair, V., Chiun, L. M., \& Singh, S. (2014). The international tourists' perspective on Malaysia's Economic Transformation Programme (ETP). Procedia-Social and Behaviours Science, 433-445.

Najam, A., Halle, M., \& MeléndezOrtiz, R. (2007). Trade and Environment. International Centre for Trade and Sustainable Development (ICTSD), 49-65.

Newman, P., \& Kenworthy, J. (1989). Cities and automobile dependence: An international sourcebook. Aldershot, UK: Gower.

Ota, T. (2017). Economic growth, income inequality and environment: Assessing the applicability of the Kuznets hypotheses to Asia. Palgrave Communications, 3, 17069 . https://doi. org/10.1057/palcomms.2017.69

Palmer, K., Oates, W. E., \& Portney, P. R. (1995). Tightening environmental standards: The benefit-cost or the nocost paradigm? Journal of Economic Perspectives, 9(4), 119-132.

Panayotou, T. (1993). Empirical Tests and Policy Analysis of Environmental Degradation at Different Stages of Economic Development, Working Paper WP238 Technology and Employment Programme, Geneva: International Labor Office .

Panayotou T. (1997) Demystifying the environmental kuznets curve: Turning a black box into a policy tool. Environment and Development Economics; 2 (4): 465484.

Pettinger, T. (2019). Benefits of economic growth. Retrieved on 21 September 2020 from https://www.economicshelp.org/macro economics/economic-growth/benefits - growth/

Porter, M. E., \& Van der Linde, C. (1995). Toward a new conception of the environmentcompetitiveness relationship. Journal of Economic Perspectives, 9(4), 97-118.

Porter, M. E. (1991). Towards a dynamic theory of strategy. Strategic Management Journal, 12, 95-117.

Saidi, K., \& Hammami, S. (2015). The effect of energy consumption and economic growth on $\mathrm{Co} 2$ emissions: Evidence from 58 countries. Bulletin of Energy Economics (BEE), The Economics and Social Development Organization (TESDO), 3(3), 91-104.

Shaari, M. S., Abdul Rahim, H., \& Abd Rashid, I. M. (2013). Relationship among population, energy consumption and economic growth in Malaysia. Int. J. Soc. Sci., 13(1), 39-45.

Shafik, N., \& Sushenjit, B. (1992). Economic growth and environmental quality: Time series and cross section evidence. Working Paper. World Development Report 1992. New York: Oxford University Press.

World Bank Report. (2020). Malaysia's economy expected to contract sharply due to COVID-19 in 2020; Growth to Rebound in 2021. Retrieved on 27 September 2020 from https:/www.worldbank.org/en/news/ press-release/2020/06/24/malaysiaseconomy-expected-to-contract-sharplydue-to-covid-19-in-2020-growth-torebound-in-2021-world-bank.

World Commission on Environment and Development (WCED). (1987). Our common future. Oxford: University Press.

York, R., Rosa, E. A., \& Dietz, T. (2003). Footprints on the earth: The environmental consequences of modernity. Am Sociol Rev, $68,279-300$.

Zibaei, M., \& Shaykh Zayn Aldin, A. (2009). Biodiversity and economic growth: A crosscountry (With emphasis on developing countries). Journal of Environmental Studies, 49, 61-72. 